\title{
DDT residues in water, sediment, domestic and indigenous biota from a currently DDT-sprayed area
}

\author{
I.E.J. Barnhoorn ${ }^{\mathrm{a},{ }^{*}, \text { M.S. Bornman }}{ }^{\mathrm{a}}$, C. Jansen van Rensburg ${ }^{\mathrm{b}}$, H. Bouwman ${ }^{\mathrm{c}}$ \\ ${ }^{a}$ Department of Urology, Faculty of Health Sciences, P.O. Box 667, University of Pretoria, Pretoria, South Africa \\ bDepartment of Animal and Wildlife Science, P.O. Box 667, University of Pretoria, Pretoria, South Africa \\ c School of Environmental Sciences and Development, North-West University, Potchefstroom, P.O. Box X6001, Potchefstroom 2520, South Africa
}

\begin{abstract}
Ab s t r a c t
DDT is used for indoor residual spraying (IRS) in Limpopo Province, northern South Africa to control malaria. Through IRS, DDT may reach the outdoor environment via dust and air and from possible spillages during application. In this area the local people consume domestic chickens, wild fish or birds. Fish from the river catchment and impoundments seem to be the major source of protein intake. Water, sediment and tissue samples from two such fish species, domestic chickens and wild birds (terrestrial and aquatic) from this DDT-sprayed area were analysed for DDT and metabolite residues. The samples contained p,p'-DDT, p,p'-DDD and p,p'-DDE residues, with the latter the most ubiquitous and in the highest concentrations. These findings raise concern that both water and food may be major routes of human exposure to DDT and metabolites, thereby posing possible adverse human health implications to the local communities.
\end{abstract}

\section{Introduction}

DDT has been used annually in the Limpopo Province in northern South Africa, and in particular the Vhembe District Municipality, since 1945 to control malaria transmission by the Anopheles funestus and Anopheles arabiensis vectors (Urbach, 2007). DDT is applied to the indoor walls and roofs of traditional unpainted mud-walled, thatched huts using indoor residual spraying (IRS) (World Health Organisation (WHO) (2002)). Once in the environment, DDT can persist as long as 15 years or is broken down to the main metabolites dichlorodiphenylchloroethane (DDE) and dichlorodiphenyldichloroethane (DDD) (Agency for Toxic Substances and Disease Registry (ATSDR) (2002)). DDE is the main and most persistent metabolite in the environment.

The various DDT metabolites and isomers are also known endocrine disruptor chemicals (EDC) as they mimic or antagonize the action of hormones (Kelce et al., 1995). These EDCs can therefore interact with physiological systems and cause alterations in development, growth, and reproduction in wildlife and particularly in exposed fish (Jobling et al., 1998). Human exposure to environmental compounds with estrogenic activity and the potential effects on human health is the subject of an ongoing scientific debate (Sharpe and Skakkebaek, 2003). There is evidence that environmental estrogens can influence the human endocrine system, and in consequence, both reproduction and tumour development (Cassidy et al., 1994; Aneck-Hahn et al., 2007). p, $\mathrm{p}^{0}$-DDE, the persistent metabolite of $\mathrm{p}, \mathrm{p}^{0}$-DDT, acts both as an androgen receptor antagonist and inhibitor of testosterone (Kelce et al., 1995; Danzo, 1997). A study by Bitman et al. (1968) indicated the estrogenic effect of $0, \mathrm{p}^{0}$-DDT on rats, when treatment with $\mathrm{o,p} \mathrm{p}^{0}$-DDT resulted in the same effects as estrogen on juvenile rat uteruses after $24 \mathrm{~h}$. Adverse reproductive system effects associated with in utero DDT or DDE exposure in male animals include, amongst others, abnormal development of ovarian tissue (Fry and Toone, 1981), reduced penis size (Guillette et al., 1994), hypospadias (Gray et al., 2001) and cryptorchidism (Facemire et al., 1995; Gray et al., 2001).

DDT was banned for agricultural purposes in South Africa in 1976 (Bouwman, 2004). Therefore, most environmental DDT residues are certainly derived from malaria control activities. Malaria areas are characterised by numerous small and large settlements and low economic development status. Since annually-applied DDT in IRS is likely to reach the outdoor environment through dust and air, as well as from possible spillages during application, the levels in exposed biota, water, sediment, and soil in malaria areas need to be understood to determine exposure pathways and sinks, possible risks to humans and the environment, and to identify possible remedial interventions. The aim of this research was to establish, interpret and report on DDT levels in domestic and wild birds, water, sediment, and fish, and to identify any human health implications these may pose. 


\section{Materials and methods}

Ethical approval (H11/2005) was obtained from the University of Pretoria and the Limpopo Provincial Government. Nature Conservation Limpopo issued appropriate permits. The respective Civic Societies of each village were consulted and gave their approvals, and the Madzivhandila College of Agriculture in Thohoyandou allowed hunting on their property.

The sampling sites are shown in Fig. 1. In the unsprayed area to the west (the upper catchment of the Luvuvhu system) were the Albasini Dam (AD), and the Tshino (TS) and Lotanyanda (LT) tributary inflows. In the downstream direction, located within the DDT-sprayed area, were the Nandoni Dam (ND), Dzwareni tributary (DT), and a quarry $(\mathrm{Q})$ (close to where the DDT-sprayed area starts), the Xikundu Weir (XW), and Site 8 (S8) close to the border of the Kruger National Park. Water and sediment samples were collected at eight sites in the Luvuvhu River. Sub-surface $(5-15 \mathrm{~cm})$ water samples were collected in clean (pre-washed with methanol) glass bottles and stored in a refrigerator until further analysis (Barnhoorn et al., 2004). Sediment was collected and placed in glass bottles (pre-washed with methanol) and stored refrigerated until analysis.

Tissue samples were collected from domestic chicken and various species of fish, terrestrial and aquatic birds. Male sharptooth catfish (Clarias gariepinus) $(\mathrm{n}=8)$ and Mozambique tilapia (Ore-ochromis mossambicus) $(\mathrm{n}=24)$ were collected using gill nets with different mesh sizes from $\mathrm{AD}, \mathrm{ND}$ and $\mathrm{XW}$. The fish were sacrificed and the available abdominal fat was collected in aluminium foil and stored at $-20{ }^{\circ} \mathrm{C}$.

Three randomly selected mature chickens from each of three DDT-sprayed villages (V1, V2 and V3) were purchased from the owners, while wild terrestrial birds (helmeted guineafowl Numida meleagris; $\mathrm{n}=3$ and Natal francolin Ptemistes natalensis; $\mathrm{n}=4$ ) as well as aquatic birds (fulvous ducks Dendrocygna bicolour; $\mathrm{n}=7$, southern pochard Netta erythrophthalma; $\mathrm{n}=1$, and Reed cormo- rant Phalacrocorax africanus; $\mathrm{n}=1$ ) were hunted using a shotgun and German pointer dogs. Available abdominal fat and liver samples of chickens and wild birds were collected and stored as for fish. Blood samples were taken from domestic goats $(n=9)$ from the three villages (V1, V2 and V3) and centrifuged at $3000 \mathrm{rpm}$ for $15 \mathrm{~min}$. The serum samples were stored at $-20^{\circ} \mathrm{C}$ until analyses.

DDT and metabolites were extracted from fat using solid phase extraction on a $\mathrm{C}_{18}$ cartridge followed by a florisil cartridge according to method Bordet et al. (2002). The analytes were eluted with petroleum ether-diethyl ether. Aldrin was used as an internal standard and quantification was accomplished via fortified calibration curve. The OCs was measured using a gas chromatography (GC) column and electron capture detection using a quadrupole mass spectrometry (MS) detector by an ISO 17025 Accredited Laboratory. Quantification was accomplished via a fortified calibration curve in matrix and the correlation coefficient was 0.99. The level of detection was $0.010 \mathrm{mg} \mathrm{kg}{ }^{1}$.

Due to the number of compounds measured in various matrixes from different locations, a multivariate analysis approach would be applicable (Borgå et al., 2005). However, since 28 fish were collected close in time and from the same aquatic system, it was decided to only include these. Inclusion of the other biological matrixes did not provide any useful interpretation, probably because different routes of exposure and transformation processes are involved. Multivariate analysis (using PC-ORD version 3.34) was conducted to investigate patterns of associations of the biology of the species and pollutants, rather than investigate associations between individual pollutants and species. We used Nonmetric Multidimensional Scaling (NMS) in preference to others, since it is generally considered as a good method of graphical representation of relationships (McCune and Grace, 2002). NMS avoids the assumption of linear relationships among variables by using ranked distances to linearise the relationships

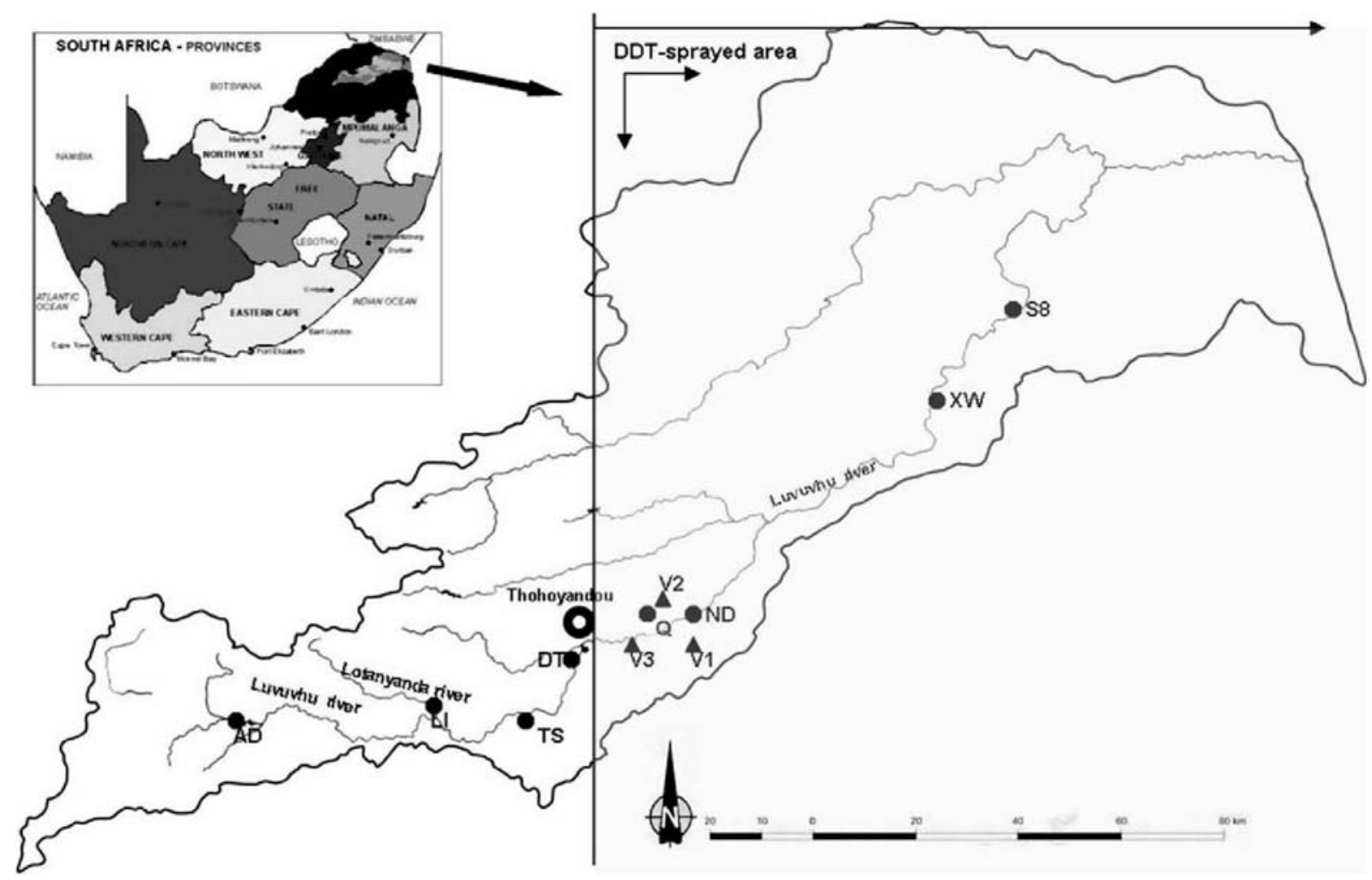

Fig. 1. The localities in the Luvuvhu river system and the villages where sampling took place in the currently DDT-sprayed and non-sprayed areas. The river runs west to east (AD = Albasini Dam; LT = Lotanyanda river; Ts = Tshino; DT = Dzwareni tributary; V1-V3 = Villages 1-3; Q = Quarry; ND = Nandoni Dam; XW = Xikundu weir). 
between measured distances in ordination space. It also allows the use of any distance measure or relativisation, and deals much better with minima (absence, or 0 for $<\mathrm{LOQ}$ ) than other ordination methods (McCune and Grace, 2002). Distance measure used was relative Euclidian distance (see McCune and Grace (2002) for discussion on distance measures). Data were relativised across columns to investigate pollution profiles using relative proportions of the pollutants and two dimensions were derived. Random starting configurations were used with 50 runs of real data. We used 50 runs of randomised data for Monte Carlo tests. Final stress can be interpreted as follows: $<5$ excellent, 5-10 good, 10-20 general picture good, but not in detail, >20 not good (McCune and Grace, 2002). Further more, two-tailed unpaired t-tests were conducted to determine the differences for $\mathrm{p}, \mathrm{p}^{0}$-DDD, $\mathrm{p}, \mathrm{p}^{0}-\mathrm{DDE}$ and RDDT between XW and ND.

\section{Results}

The levels of DDT and metabolites in water are summarized in Table 1. p, $\mathrm{p}^{0}$-DDE was the most prevalent metabolite, but occurred unexpectedly also at the non-sprayed sites. In sediment some

Table 1

DDT and metabolites in the water collected from the Luvuvhu river system (detection limit $0.00005 \mathrm{mg} \mathrm{L}^{1}$ ).

\begin{tabular}{llllc}
\hline \hline \multicolumn{1}{c}{ Water (mgL ${ }^{1}$ ) } & $p, p^{\prime}$-DDT & $p, p^{\prime}$-DDD & $p, p^{\prime}$-DDE & EDDT \\
\hline Albasini Dam & bdl & bdl & bdl & bdl \\
Tshino & bdl & bdl & 0.0003 & 0.003 \\
Lotanyanda & bdl & bdl & 0.0013 & 0.0013 \\
Nandoni Dam & bdl & bdl & 0.0014 & 0.0014 \\
Dzwareni & bdl & bdl & bdl & bdl \\
Quarry & bdl & 0.0012 & bdl & 0.0012 \\
Xikundu Weir & bdl & bdl & 0.0007 & 0.007 \\
Site 8 & bdl & 0.0011 & bdl & 0.0011 \\
\hline
\end{tabular}

bdl = below detection limit.

Table 2

DDT and metabolite residues in fish fats $\left(\mathrm{mg} \mathrm{kg}^{-1}\right)$ from Nandoni Dam and the

\begin{tabular}{|c|c|c|c|}
\hline Fat $\left(\mathrm{mgkg}^{1}\right)$ & o,p'-DDT & $p, p^{\prime}$-DDT & $0, p^{\prime}-D D D$ \\
\hline OMX1 & 0.281 & 4.671 & 0.071 \\
\hline OMX2 & 0.206 & 4.424 & 0.064 \\
\hline OMX3 & 0.462 & 7.54 & 0.063 \\
\hline OMX4 & 0.296 & 5.895 & 0.053 \\
\hline OMX5 & 0.238 & 6.477 & 0.05 \\
\hline OMX6 & bdl & 1.063 & 0.061 \\
\hline OMX7 & bdl & 0.92 & 0.05 \\
\hline OMX8 & 0.103 & 3.819 & 0.065 \\
\hline OMX9 & 0.337 & 0.721 & bdl \\
\hline OMX10 & 0.163 & 0.415 & bdl \\
\hline OMX11 & 0.075 & 0.184 & bdl \\
\hline OMX12 & 0.526 & 3.195 & 0.033 \\
\hline OMX13 & 0.21 & 0.483 & bdl \\
\hline OMN1 & bdl & 0.114 & bdl \\
\hline OMN2 & bdl & 0.085 & bdl \\
\hline OMN3 & bdl & bdl & bdl \\
\hline OMN4 & bdl & bdl & bdl \\
\hline OMN5 & bdl & bdl & bdl \\
\hline OMN6 & bdl & bdl & bdl \\
\hline OMN7 & bdl & bdl & bdl \\
\hline OMN8 & bdl & 0.157 & bdl \\
\hline OMN9 & bdl & bdl & bdl \\
\hline OMN10 & bdl & bdl & bdl \\
\hline CGN2 & bdl & bdl & 0.021 \\
\hline CGN3 & bdl & bdl & bdl \\
\hline CGN4 & bdl & bdl & 0.051 \\
\hline CGX & 2.466 & 6.598 & 0.444 \\
\hline CGAW & 0.176 & 2.38 & 0.193 \\
\hline
\end{tabular}

metabolites and isomers were present but the levels were lower than the quantification limit and not quantifiable $\left(<0.02 \mathrm{mg} \mathrm{kg}^{-1}\right)$.

Table 2 summarizes the DDT isomers and metabolite levels in fish fat. 0. mossambicus from $\mathrm{AD}$ had no fat, and no C. gariepinus were found at this locality. 0. mossambicus from XW had higher levels of all the metabolites and isomers compared to ND (Table 2); XW fish had 20-times higher SDDT levels (Fig. 2). Two-tailed unpaired t-tests showed highly significant $(\mathrm{p}<0.0005)$ differences for p,p'-DDD, p,p'-DDE and SDDT between XW and ND. In $\mathbf{0}$ mossambicus the mean\% p,p'-DDE of the SDDT was $27 \%$ at XW and $71 \%$ for the same species from ND. C. gariepinus from XW had very high levels of all the metabolites and isomers (min: 0.051 mgkg $^{-1}$ o,p'-DDE and max: $63 \mathrm{mg} \mathrm{kg}^{-1} \mathrm{p}, \mathrm{p}^{\prime}$-DDE) compared to the fish from the farm outside the sprayed area (CGAW) (Table 2).

Fig. 3 shows the NMS joint plot for fish. The distance between the points (samples) is approximately proportional to the dissimilarities between them. Only two dimensions were derived. The final stress was 1.073 reached after 63 iterations. Final instability was 0.00001 . The Monte Carlo tests were significant for both Axis 1 ( $p=$ $0.016)$ and Axis $2(p=0.020)$. Axis 1 explained $5.3 \%$ of the variation, and Axis 2, 71.1\%, for a cumulative explanation of $76.5 \%$, and adjusted cumulative of 97.1\%. 0. mossambicus from XW (OMX) was located mostly to the left, and those from ND (OMD) clustered more tightly to the right. o,p'-DDT, o,p'-DDE and p,p'-DDT was associated with XW, and p,p'-DDE with the ND 0. mossambicus. All C. gariepinus were located in the upper right quadrant, associated strongly with p,p'-DDE.

DDT and metabolite concentrations in the liver of terrestrial and aquatic birds are shown in Table 3. Finding francolins and guinea fowls were very difficult due to low population densities. Samples from only seven terrestrial and nine aquatic birds could be collected. Although fat tissue was also collected from wild birds, insufficient amounts were available, therefore only liver tissue was used for DDT analysis. Because little fat could be obtained from the chickens, the fat samples collected were pooled per

weir.

\begin{tabular}{|c|c|c|c|}
\hline$p, p^{\prime}$-DDD & $0, \mathrm{p}^{0}-\mathrm{DDE}$ & p,p'-DDE & EDDT \\
\hline 2.766 & bdl & 4.073 & 11.862 \\
\hline 3.169 & bdl & 4.206 & 12.069 \\
\hline 2.618 & bdl & 3.697 & 14.38 \\
\hline 2.889 & bdl & 3.797 & 12.93 \\
\hline 3.082 & bdl & 3.141 & 12.988 \\
\hline 2.733 & bdl & 3.71 & 7.567 \\
\hline 2.302 & bdl & 4.124 & 7.396 \\
\hline 3.751 & bdl & 3.771 & 11.509 \\
\hline 0.872 & 0.025 & 1.171 & 3.126 \\
\hline 0.334 & 0.013 & 0.197 & 1.122 \\
\hline 0.077 & 0.019 & bdl & 0.355 \\
\hline 1.439 & 0.028 & 2.067 & 7.288 \\
\hline 0.591 & 0.019 & 0.506 & 1.809 \\
\hline 0.076 & bdl & 0.219 & 0.409 \\
\hline 0.094 & bdl & 0.249 & 0.428 \\
\hline 0.071 & bdl & 0.234 & 0.305 \\
\hline 0.086 & bdl & 0.236 & 0.322 \\
\hline 0.076 & bdl & 0.258 & 0.334 \\
\hline 0.059 & bdl & 0.22 & 0.279 \\
\hline 0.077 & bdl & 0.252 & 0.329 \\
\hline 0.174 & bdl & 0.525 & 0.856 \\
\hline 0.076 & bdl & 0.334 & 0.41 \\
\hline 0.082 & bdl & 0.286 & 0.368 \\
\hline 0.415 & bdl & 1.906 & 2.342 \\
\hline 0.265 & bdl & 1.255 & 1.52 \\
\hline 0.869 & bdl & 3.215 & 4.135 \\
\hline 8.47 & 0.051 & 63.462 & 81.491 \\
\hline 4.036 & 0.051 & 17.178 & 24.014 \\
\hline
\end{tabular}

bdl = below detection limit; OM = O. mossambicus; CG = C. gariepinus; $\mathrm{X}=$ Xikundu Weir; $\mathrm{N}$ = Nandoni Dam; AW = Farm outside sprayed area. 


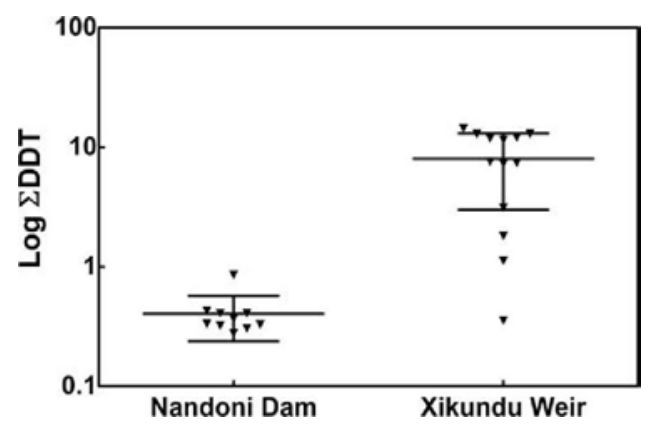

Fig. 2. Two-tailed unpaired r-tests showed highly significant differences $(\mathrm{p}<0.0005)$ for EDDT levels in 0. mossambicus from ND and XW.

village for analysis (Table 3). p,p'-DDT (12-, 3.5- and $3.5 \mathrm{mg} \mathrm{kg}{ }^{-1}$ ), and particularly p,p'-DDE (7.1-, 5- and $\left.12 \mathrm{mgkg}^{-1}\right)$, were found in free roaming chickens (Table 3). Serum samples collected from domestic goats had no DDT and metabolite concentrations above the detection limit of $0.02 \mathrm{mg} \mathrm{LT}^{1}$.

\section{Discussion}

The DDT levels found in water (Table 1) were all well below the drinking water guideline of $2 \mathbf{u}$.g L ${ }^{-1}$ (WHO, 2002), and therefore unlikely to pose a risk to humans directly using this source. However, during and just after spraying, the levels may well be higher and should be measured. Furthermore, the presence of DDT and metabolites in water may also have an effect on aquatic life. DDT, DDE, and DDD are lipid soluble (Howard and Meylan, 1997) and combined with a long half-life, results in high bioconcentra-tion in aquatic organisms, as has been found elsewhere in South Africa (Bouwman et al., 1990). Aquatic animals feed on other organisms at lower trophic levels and subsequently progressive biomagnification of DDT occur in animals in higher trophic levels, including birds that might be affected (ATSDR, 2002). This concern seems warranted considering the levels of DDT and metabolites in fish tissue (Table 2 and Fig. 2). The DDTs (DDT, DDE and DDD), once taken up, distribute to various organs. The metabolism of p,p'-DDE is slow in fatty tissue and acts as a repository forp,p'-DDE (ATSDR, 2002).

Fig. 3 furthermore shows a change in DDT profile from up- to downstream in 0. mossambicus which should be taken into account when considering fish intake in risk assessments in catchment systems. The upstream (ND) association of $\mathbf{0}$. mossambicus with $p, p^{\prime}$-DDE (Fig. 3), and the downstream association of the same species with p,p'-DDT, o,p'-DDT and o,p'-DDE indicates that more parent p,p'-DDT, as well as o,p'-DDT (which makes up 22\% of the applied formulation) enters the aquatic system further into the malaria applied area and is taken up by this species. Some possible movement

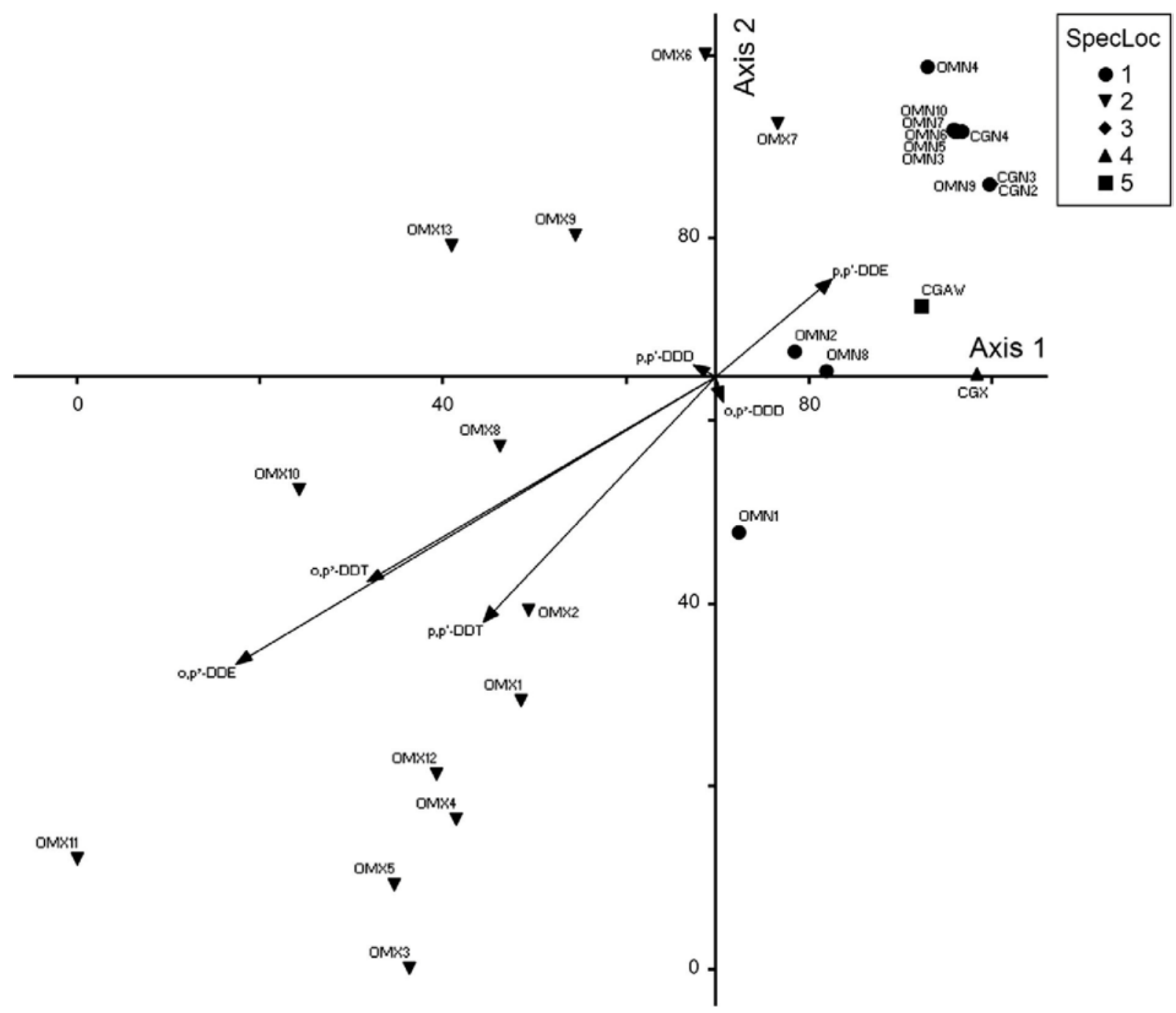

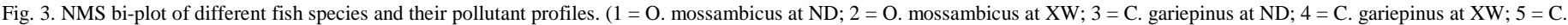
gariepinus outside DDT-sprayed area). 
Table 3

DDT and metabolite residues in livers of terrestrial and aquatic bir $\left(\mathrm{mg} \mathrm{kg}^{1}\right)$ from the DDT-sprayed area and in the fat (mgkg $\left.{ }^{1}\right)$ of the domestic chickens from three villages.

\begin{tabular}{|c|c|c|c|c|c|c|c|c|c|}
\hline $\begin{array}{l}\text { Terrestrial bird } \\
\text { species liver } \\
\left(\text { mgkg }^{1}\right)\end{array}$ & $\begin{array}{l}\text { Helmeted guinea fowl } \\
\text { Numida meleagris }(\mathrm{n}=3)\end{array}$ & & & $\begin{array}{l}\text { Natal francolin } \\
\text { Pternistes natalensis } \\
(\mathrm{n}=4)\end{array}$ & & & & & \\
\hline p,p'-DDT & bdl & bdl & bdl & bdl & bdl & bdl & bdl & & \\
\hline$p, p^{\prime}-\mathrm{DDE}$ & bdl & bdl & 0.02 & 0.12 & 0.05 & bdl & bdl & & \\
\hline$p, p^{\prime}-\mathrm{DDD}$ & 0.01 & 0.07 & 0.09 & 0.42 & 0.18 & 0.02 & 0.06 & & \\
\hline $\begin{array}{c}\text { Aquatic bird species } \\
\text { liver }\left(\mathrm{mgkg}^{-1}\right)\end{array}$ & $\begin{array}{l}\text { Fulvous duck D. bicolour } \\
(\mathrm{n}=7)\end{array}$ & & & & & & & $\begin{array}{l}\text { Southern pochard N. } \\
\text { erythrophthalma } \\
\text { africanus }\end{array}$ & $\begin{array}{l}\text { Reed } \\
\text { cormorant P. }\end{array}$ \\
\hline p,p'-DDT & bdl & bdl & bdl & bdl & bdl & bdl & bdl & bdl & bdl \\
\hline $\begin{array}{l}\text { p,p'-DDD } \\
\text { p,p'-DDE }\end{array}$ & $\begin{array}{l}\text { bdl } \\
\text { bdl }\end{array}$ & $\begin{array}{l}\text { bdl } \\
\text { bdl }\end{array}$ & $\begin{array}{l}\text { bdl } \\
\text { bdl }\end{array}$ & $\begin{array}{l}\text { bdl } \\
\text { bdl }\end{array}$ & $\begin{array}{l}\text { bdl } \\
0.7\end{array}$ & $\begin{array}{c}\text { bdl } \\
0.02\end{array}$ & $\begin{array}{l}\text { bdl } \\
\text { bdl }\end{array}$ & $\begin{array}{l}\text { bdl } \\
\text { bdl }\end{array}$ & $\begin{array}{l}0.12 \\
4.54\end{array}$ \\
\hline $\begin{array}{c}\text { Domestic chickens } \\
\text { fat }\left(\mathrm{mgkg}^{\prime 1}\right)\end{array}$ & Chickens V1 $(\mathrm{n}=3)$ & $\begin{array}{l}\text { Chickens } \\
\text { V2 }(n=3)\end{array}$ & $\begin{array}{l}\text { Chickens } \\
\text { V3 }(n=3)\end{array}$ & & & & & & \\
\hline$p, p^{\prime}-\mathrm{DDE}$ & 7.1 & 5 & 12 & & & & & & \\
\hline p,p'-DDD & 2.1 & 2.5 & 21 & & & & & & \\
\hline p,p'-DDT & 12 & 3.5 & 3.5 & & & & & & \\
\hline
\end{tabular}

of fish is indicated by OMN1, OMN2 and OMN8 which lie closer to the Xikundu fish DDT profiles (Fig. 3). This would have had to happen however, before the dam wall was completed. The DDT profile differences of $\mathbf{0}$. mossambicus up- and downstream is, however, not reflected in the profile of the omnivorous catfish, but only few samples were collected to make any conclusive statements. Since most of the observed variation was attributed to Axis 1 (71.1\%), this dimension most likely reflect the cumulative runoff of DDTs from the increasing number of the DDT-sprayed villages as the river flows into the DDT-sprayed area. Therefore, not only is there a possible increase in risk (from fish dietary intake) attributable to an increase in levels in fish from upstream to downstream (Table 2 and Fig. 2), there is also a possible change in endocrine disrupting effects as the DDT-profile changes (Fig. 3). o,p'-DDT is estrogenic (Bitman et al., 1968) and p,p'-DDE acts both as an androgen receptor antagonist and as inhibitoroftestosterone(Kelceetal., 1995; Danzo, 1997). Exposure of fish embryos during development to estrogens (Hunter and Donaldson, 1983) or estrogen mimicking chemicals (Gi-meno et al., 1996) may induce intersexuality or the presence of tes-ticular oocytes in males. Therefore, it seems possible that $\mathbf{0}$. mossambicus males at XW may have a higher probability of developing intersex and this should be followed up in further studies.

The levels found in liver of terrestrial birds (Table 3) were higher when compared to the findings of Lötter and Bouwman (2001) where liver levels of p,p'-DDE (9|j.gkg- $\left.{ }^{1}\right)$ and p,p'-DDD (25 j.gkg $\left.{ }^{1}\right)$ in helmeted guineafowl (a terrestrial bird) were the major analysed compounds present from two DDT-sprayed localities. One possible route of uptake by terrestrial birds concern affected insects that leave the sprayed dwellings and then get consumed by insectivorous birds in the vicinity. Unpublished data $(\mathrm{H}$. Bouwman) from another DDT-sprayed area in South Africa (KwaZulu-Natal) has shown small insectivorous birds (red-capped robin chat, Cossypha natalensis, and brown scrub-robin, Cercotrichas signata) with DDT blood levels comparable to published levels in pied kingfishers (Ceryle rudis), a piscivorous bird from the same system (Evans and Bouwman, 2000), indicating affected insects as a possible route of uptake.

Little is known in Africa on relationships between pollutants in fish and piscivorous birds. Evans and Bouwman (1993) found low levels of DDT in duck liver in northern Kwazulu-Natal (mean of 23 and $49 \mathrm{u.g} \mathrm{kg}{ }^{-1}$ SDDT (wet mass) in 16 white-faced (Dendrocy-gna viduata) and six yellow-billed (Anas undulata) ducks, respectively), but higher levels in seven $\mathbf{0}$. mossambicus muscle tissue samples (mean of 95 u.gkg $^{-1}$ SDDT (wet mass; Bouwman et al., 1990) from the same area, indicating biomagnification in areas where DDT is sprayed. African fish eagles (Haliaeetus vocifer), Afri- can darters (Anhinga rufa) and reed cormorants (P. africanus) inhabit the same areas and predate primarily on fish. Birds are most likely exposed to DDT from consumed fish, as illustrated by the DDT levels in reed cormorant when compared with the ducks (Table 2) which are mainly vegetarian. Research from the Great Lakes (North America) indicated that $\mathrm{p}, \mathrm{p}^{0}$-DDE inhibited the reproductive success of the bald eagles (Haliaeetus leucocephalus) by thinning of the egg shells (Bowerman et al., 1998). $\mathrm{p}, \mathrm{p}^{0}$-DDE induced eggshell thinning resulted in crushed eggs and breeding failure of piscivorous birds (Fry, 1995). Also, a study by Bouwman et al. (2008) indicated eggshell thinning in the African darter (aquatic feeding bird) from another area in South Africa where DDT is not used for malaria control at levels lower than expected, indicating increased sensitivity or other biological and/or chemical factors. However, further research on aquatic birds are needed, especially those in higher tropic levels, such as kingfishers and African darters.

\subsection{Human health aspects}

The presence of $\mathrm{p}, \mathrm{p}^{0}$-DDT residues and particularly $\mathrm{p}, \mathrm{p}^{0}$-DDE in chicken that share the immediate environment with humans is a reason for concern. Their contamination is likely related to the use of DDT for malaria control and chickens should further be evaluated as possible animal biomarker for human IRS exposures. Rural chickens probably have an average life span of 2 years and both the eggs and the meat might be dietary sources of DDT intake by humans.

Furthermore, local people consume fish from rivers as an important and sometimes only protein source (own observations and Bouwman et al., 1990) and therefore increasing possible health risks associated with DDTs. Table 2 and Fig. 2 show an increase in DDT levels in the downstream direction, indicating a possible concomitant increase in human risk associated with higher levels of pollution in this protein source. Determining the possible human health risk associated with consumption of fish in the various areas, is now being studied as a matter of urgency.

We have shown that in an aquatic system flowing into a DDT-sprayed area, changes in DDT levels and profiles in fish occur that has not previously been identified, and that might impact on human health and other biota. Although the levels of DDT in water are low, bioconcentration, as well as biomagnification seems to be in effect, but further trophic-level research, and especially human consumption patterns of fish, is needed for to determine possible risk. Also, since wild terrestrial birds also showed detectable levels, it needs further investigation as to routes of uptake. Finally, chickens had very high levels, and may be an important route of uptake by inhabitants of sprayed dwellings. Both wild and 
domestic bird parameters indicate the importance of having to consider and investigate how IRS-applied DDT can find its way to the outdoor environment and river systems.

\section{Acknowledgements}

The authors acknowledge the Water Research Commission of South Africa, the National Research Foundation and the Post-doctoral Fellowship Programme, University of Pretoria for funding. Also Ms AEC Burger, a consultant for the Endocrine Disrupter Research Programme of the Water Research Commission for her scientific input and support.

References

Agency for Toxic Substances and Disease Registry (ATSDR), 2002. Toxicological profile for DDT, DDE, DDD. US Department of Health and Human Services, Public Health Service, Atlanta, GA. Aneck-Hahn, N.H., Schulenburg, G.W.,

Bornman, M.S., Farias, P., de Jager, C., 2007.

Impaired semen quality associated with environmental DDT exposure in young men living in a malaria area in the Limpopo Province, South Africa. J. Androl. 28 (3), 423-434. Barnhoorn, I.E., Bornman, M.S., Pieterse, G.M., Van Vuren, J.H.,

2004. Histological

evidence of intersex in feral sharptooth catfish (Clarias gariepinus) from an estrogen-polluted water source in Gauteng, South Africa. Environ. Toxicol. 19,

603-608. Bitman, J., Cecil, H.C., Harris, S.J., Fries, G.F., 1968. Estrogenic activity of o,p prime-DDT in the mammalian uterus and avian oviduct. Science 162, 371-372.

Bordet, F., Inthavong, D., Fremy, J., 2002. Interlaboratory study of a multiresidue gas chromatographic method for determination of organochlorine and pyrethroid pesticides and polychlorobiphenyls in milk, fish, eggs and beef fat. Int. J. AOAC 85 (6), 1398-1409. Borgå, K., Gabrielsen, G.W., Skaare, J.U., Kleivane, L.,

Norstrom, R.J., Fisk, A.T., 2005.

Why do organochlorine differences between Arctic regions vary among trophic levels? Environ. Sci. Technol. 39, 4343-4352. Bouwman, H., 2004. South Africa

and the Stockholm convention on persistent organic pollutants. SA. J. Sci. 100, 323-328. Bouwman, H., Coetzee, A.,

Schutte, C.H.J., 1990. Environmental and health implications of DDT-contaminated fish from the Pongolo flood plain. Afr. J. Zool. 104, 275-286. Bouwman, H., Polder, A., Venter, B., Skaare, J.U., 2008.

Organochlorine contaminants in cormorant, darter, egret and ibis eggs from South Africa. Chemosphere 71, 227-241. Bowerman, W.W., Best, D.A., Grubb, T.G., Zimmerman, G.M., Giesy, J.P.,

1998. Trends

of contaminants and effects in bald eagles of the Great Lakes basin. Environ. Monit. Assess. 53, 197-212.
Cassidy, R.A., Vorhees, C.V., Minnema, D.J., Hastings, L., 1994. The effects of chlordane exposure during pre- and post-natal periods at environmentally relevant levels on sex steroid-mediated behaviors and functions in the rat. Toxicol. Appl. Pharmacol. 126 (2), 326-337. Danzo, B., 1997. Environmental

xenobiotics may disrupt normal endocrine function by interfering with the binding of physiological ligands to steroid receptors and binding proteins. Environ. Health Perspect. 105 (3), 294-301. Evans, S.W.

Bouwman, H., 1993. Levels of DDT in the liver tissue of two duck species from the Pongolo Floodplain. Ostrich 64, 46-47. Evans, S.W., Bouwman,

H., 2000. The geographic variation and potential risk of DDT in the blood of Pied Kingfishers from the northern KwaZulu-Natal, South Africa. Ostrich, 351-354. Facemire, C.F., Gross, T.S., Guilette, L.J., 1995. Reproductive impairment in the

Florida panther: nature or nurture? Environ. Health Perspect. 103 (suppl. 4), 79-86. Fry, D.M., 1995. Reproductive effects in birds exposed to pesticides and industrial

chemicals. Environ. Health Perspect. 103 (suppl. 7), 165-171. Fry, D.M., Toone,

C.K., 1981. DDT-induced feminization of gull embryos. Science 213, 93-95. Gimeno, S., Gerritsen, A., Bowmer, T., Komen, H., 1996. Feminization of male carp.

Nature 384, 221-222. Gray, L.E., Ostby, J., Furr, J., Wolf, C.J., Lambright, C., Parks,

L., Veeramachaneni, D.N.

Wilson, V., Price, M., Hotchkiss, A., Orlando, E., Guillette, L., 2001. Effects of environmental antiandrogens on reproductive development in experimental animals. Hum. Reprod. Update 7 (3), 248-264. Guillette, L.J., Gross, T.S., Masson,

G.R., Matter, J.M., Franklin Percival, H., Woodward,

A.R., 1994. Developmental abnormalities of the gonad and abnormal sex hormone concentrations in juvenile alligators from contaminated and control lakes in Florida. Environ. Health Perspect. 102, 680-688. Howard, P., Meylan, W.,

1997. Handbook of Physical Properties of Organic

Chemicals. CRC Press, Lewis Publishers, Boca Raton, FL. Hunter, G.A., Donaldson,

E.M., 1983. In: Hoar, W.S., Randall, D.J., Donaldson, E.M.

(Eds.), Fish Physiology. Academic Press, New York. Jobling, S., Nolan, M., Tyler,

C.R., Brighty, G., Sumpter, J.P., 1998. Widespread sexual

disruption in wild fish. Environ. Sci. Technol. 32, 2498-2506. Kelce, W., Stone, C.

Laws, S., et al., 1995. Persistent DDT metabolite p, $\mathrm{p}^{0}-\mathrm{DDE}$ is a potent androgen receptor antagonist. Nature 375, 581-585. Lötter, L., Bouwman, H., 2001. Organochlorine pesticide residues in helmeted guineafowl (Numida meleagris), South Africa. Bull. Environ. Contam. Toxicol. 66, 162-170. McCune, B., Grace, J.B., 2002. Analysis of ecological communities. MjM Software

Design, Gleneden Beach, Oregon. Sharpe, R.M., Skakkebaek, N.E., 2003. Male

reproductive disorders and the role of

endocrine disruption: advances in understanding and identification of areas for future research. Pure Appl. Chem. 75, 2023-2038. Urbach, J., 2007. Inconclusive

study on DDT has potentially mortal consequences.

Human Health Policy. May 2007. <http://www.healthpolicyunit.org/scripts/ documents/ $>$ (accessed 19.06.08). World Health Organisation (WHO), 2002.

Application of Residual Sprays for Vector Control: Manual for Indoor Residual Spraying. WHO/CDS/Whopes/GCDPP/ 2000.3. World Health Organization, Geneva. 